\title{
Quantifying water and salt fluxes in a lowland polder catchment dominated by boil seepage: a probabilistic end-member mixing approach
}

\author{
P. G. B. de Louw ${ }^{1}$, Y. van der Velde ${ }^{2,3}$, and S. E. A. T. M. van der Zee \\ ${ }^{1}$ Deltares, Department Soil and Groundwater, P.O. Box 85467, 3508 AL Utrecht, The Netherlands \\ ${ }^{2}$ Wageningen University, Environmental Sciences Group, Soil Physics, Ecohydrology and Groundwater Management, \\ P.O. Box 47, 6700 AA Wageningen, The Netherlands \\ ${ }^{3}$ Wageningen University, Environmental Sciences Group, Hydrology and quantitative water management, P.O. Box 47, \\ 6700 AA Wageningen, The Netherlands
}

Received: 7 December 2010 - Published in Hydrol. Earth Syst. Sci. Discuss.: 11 January 2011

Revised: 8 June 2011 - Accepted: 1 July 2011 - Published: 7 July 2011

\begin{abstract}
Upward saline groundwater seepage is leading to surface water salinization of deep lying polders in the Netherlands. Identifying measures to reduce the salt content requires a thorough understanding and quantification of the dominant sources of water and salt on a daily basis. However, as in most balance studies, there are large uncertainties in the contribution from groundwater seepage. Taking these into account, we applied a probabilistic (GLUE) endmember mixing approach to simulate two years of daily to weekly observations of discharge, salt loads and salt concentration of water pumped out of an artificially drained polder catchment area. We were then able to assess the contribution from the different sources to the water and salt balance of the polder and uncertainties in their quantification. Our modelling approach demonstrates the need to distinguish preferential from diffuse seepage. Preferential seepage via boils contributes, on average, $66 \%$ to the total salt load and only about $15 \%$ to the total water flux into the polder and therefore forms the main salinization pathway. With the model we were able to calculate the effect of future changes on surface water salinity and to assess the uncertainty in our predictions. Furthermore, we analyzed the parameter sensitivity and uncertainty to determine for which parameter the quality of field measurements should be improved to reduce model input and output uncertainty. High frequency measurements of polder water discharge and weighted concentration at the outlet of the catchment area appear to be essential for obtaining reliable simulations of water and salt fluxes and for allotting these to the different sources.
\end{abstract}

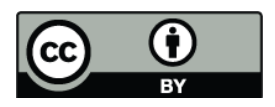

Correspondence to: P. G. B. de Louw (perry.delouw@deltares.nl)

\section{Introduction}

Salinization of surface waters and aquifers is common in coastal areas (Custodio and Bruggeman, 1987; Post and Abarca, 2010) and deltas; in particular; are vulnerable to processes that may enhance salinization, such as land subsidence, climate change and sea-level rise (Oude Essink, 2008). As one-quarter of the Netherlands lies below mean sea level, upward seepage of saline and nutrient-rich groundwater causes salinization and eutrophication of its surface waters (van Rees Vellinga et al., 1981; van Puijenbroek et al., 2004; van der Eertwegh et al., 2006). This seepage makes the surface water unfit for irrigation and adversely affects aquatic ecosystems. Both surface water quality issues typically play a role during the dryer and warmer growing season, when the demand for fresh water increases but its availability is limited. Future rises in sea level and climate change are expected to increase the seepage and decrease the availability of fresh water (e.g. Sherif and Singh, 1999; Ranjan et al., 2006; Vandenbohede et al., 2008), especially in the deep polders (Oude Essink et al., 2010). To determine effective measures for reducing the salt loads in the deep polders we need to identify and quantify the main sources of water and salt. In this paper we will set up daily water and salt balances to help understand the dynamics observed in salt concentrations (De Louw et al., 2010) and to signal problems with salinization during the growing season.

A polder is an artificially drained catchment in which the surface water level in the ditch network is regulated by pumping. Water pumped out of a polder is a mixture of seepage water from the upper aquifer, precipitation and water admitted from a "boezem", which is a higher lying surface water canal used for buffering polder water (Fig. 1). De

Published by Copernicus Publications on behalf of the European Geosciences Union. 


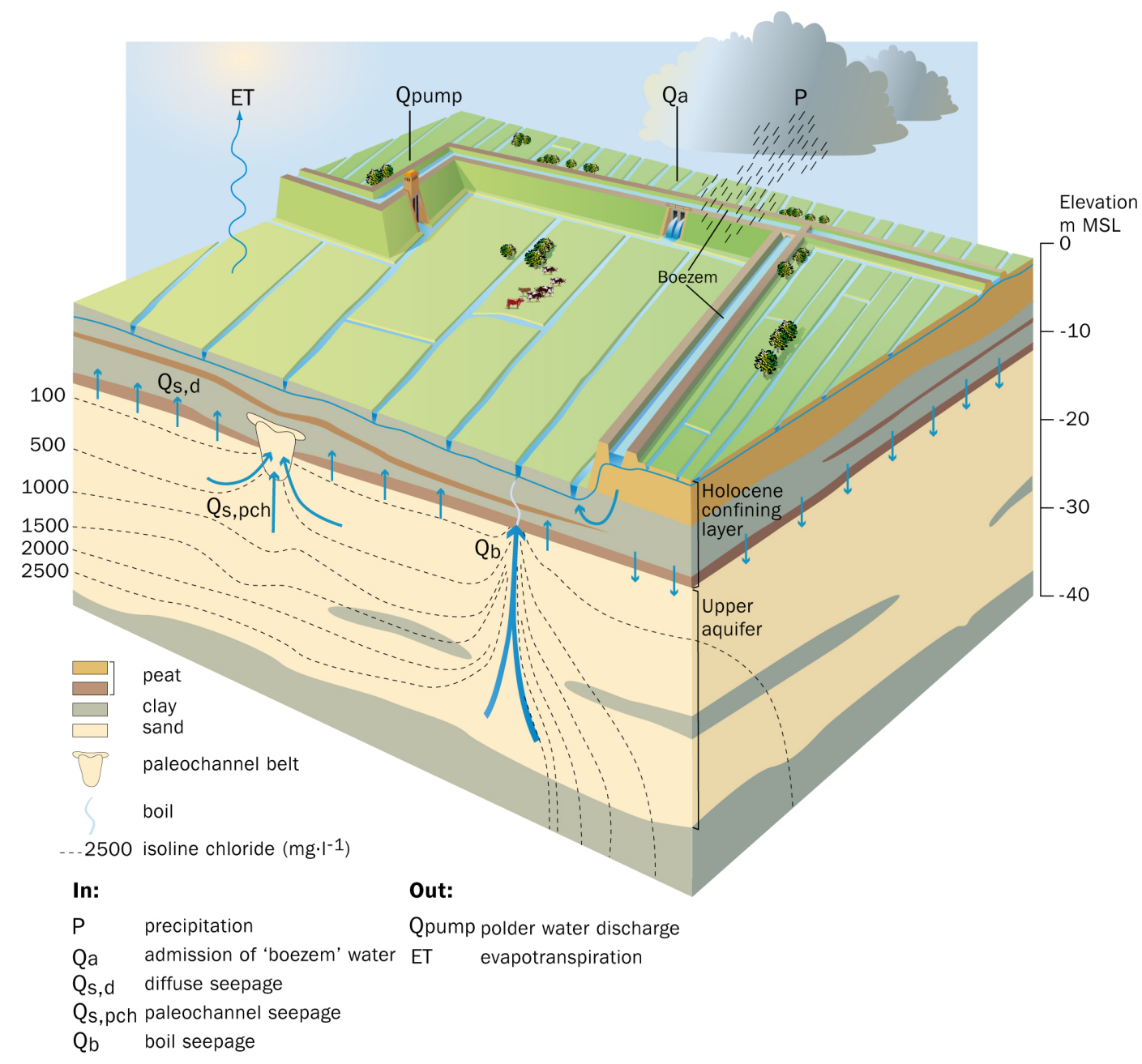

Fig. 1. The geohydrology and water and salt fluxes in a lowland polder catchment area. Upward groundwater seepage from the upper aquifer can be divided into three different types according to De Louw et al. (2010): diffuse-, paleochannel-, and boil seepage.

Louw et al. (2010) distinguished three types of groundwater seepage in a deep polder which differ in flux and salt concentration: (1) diffuse, background seepage through the Holocene confining layer, (2) preferential seepage through permeable, sandy paleochannel belts in the Holocene confining layer, and (3) intense preferential seepage via boils (Fig. 1). Boils are small vents in the Holocene confining layer through which water discharges at high rates and which lead to strong upconing of deeper and more saline groundwater (Fig. 1). De Louw et al. (2010) presented evidence that preferential seepage via boils is the main salt source of surface waters in deep polders. In general, the contribution of groundwater seepage to stream discharge and quality is difficult to infer directly from field data for several reasons. First, seepage fluxes are highly variable in space and are difficult to measure directly (e.g. Kalbus et al., 2009; Keery et al., 2007; Surridge et al., 2005; Murdoch and Kelly, 2003; Kishel and Gerla, 2002). Second, the composition of groundwater seepage varies spatially and deriving a representative average composition would require a large number of measurements. And third, mapping of preferential groundwater flow routes such as boils for large catchments is an enormous task (Becker et al., 2004; van Schaik, 2009; De Louw et al., 2010).

Alternatively, an end-member mixing approach (EMMA, Hooper et al., 1990) can be applied to estimate seepage fluxes of water and salt indirectly from discharge and concentration measurements at the catchment outlet. EMMA assumes that solute concentrations in a stream result from the mixing of two or more flow routes with a known concentration ("endmembers") and it is often used for hydrograph separation into contributions of individual flow routes (e.g. Tiemeyer et al., 2008; Soulsby et al., 2003; van der Velde et al., 2010). Given the uncertainty of fluxes and concentration of the different sources only a combination of EMMA with an uncertainty and sensitivity assessment will yield meaningful estimations of individual flow routes. A method to determine the uncertainty of model predictions and model parameters - 
Study area Noordplas Polder
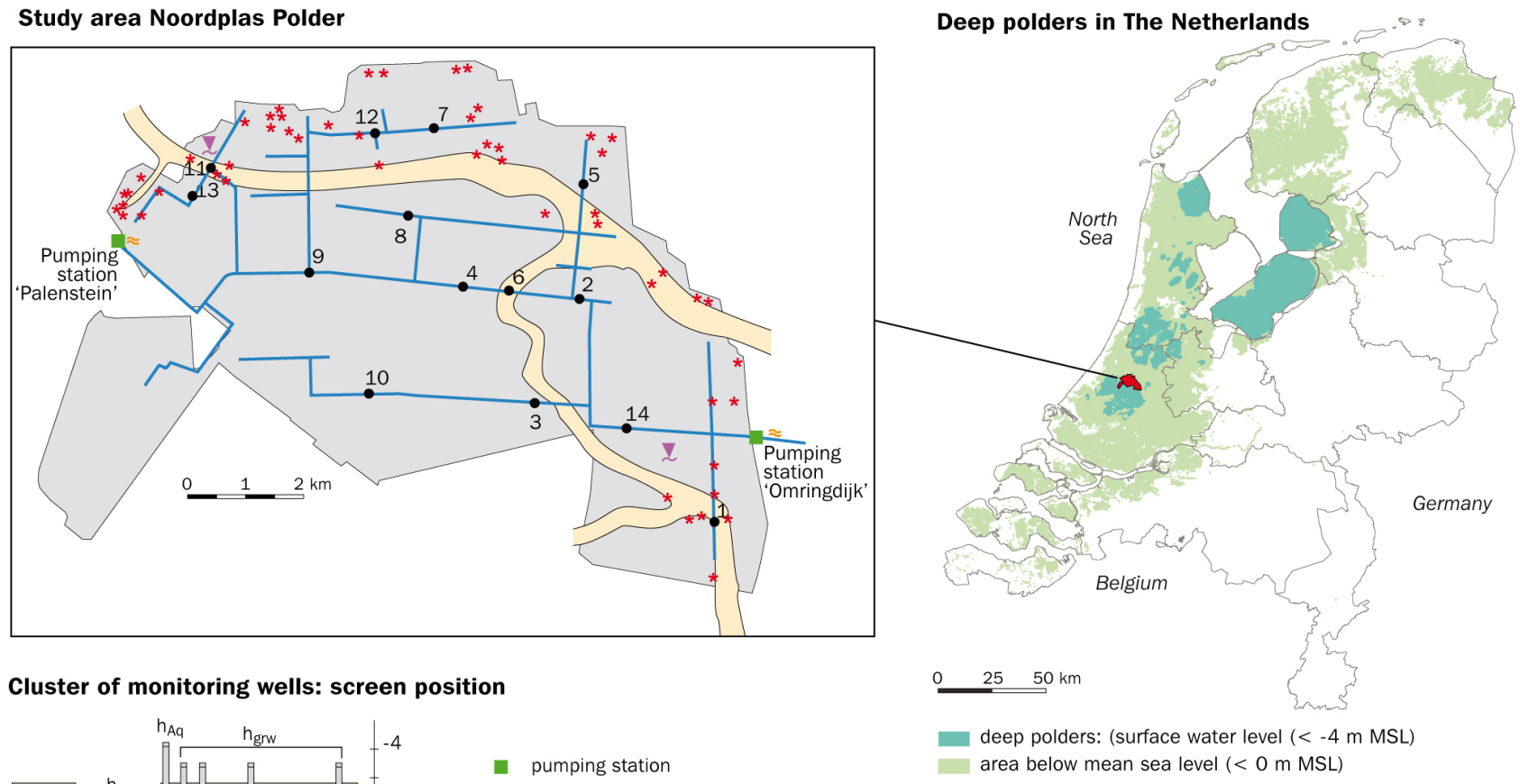

Cluster of monitoring wells: screen position

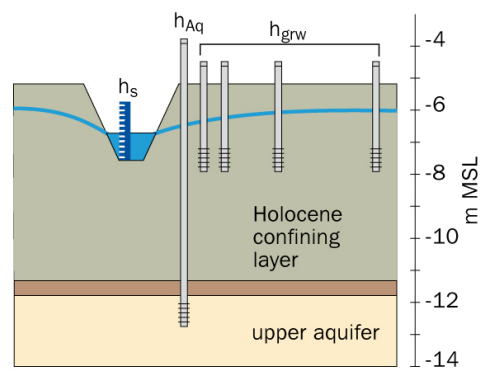

- pumping station

$\approx$ discharge proportional sampling equipment

$\beth$ rain gauge

- main ditches

= paleochannel belt in confining layer

* boils

- ${ }^{10}$ cluster of monitoring wells

$h_{s}$ surface water level

$h_{\text {grw }}$ groundwater level

$h_{A q}$ hydraulic head

Fig. 2. Set up of the monitoring network of the Noordplas Polder and the location of the sandy paleochannel belts and boils (adapted from De Louw et al., 2010).

generalized likelihood uncertainty estimation (GLUE, Beven and Binley, 1992) - is broadly used due to its conceptual simplicity, ease of implementation and versatility at handling different models without major modifications to the method itself (Blasone et al., 2008a,b; Benke et al., 2008; Tiemeyer et al., 2008; Kuczera and Parent, 1998; Freer et al., 1996). The problem of equifinality, where different parameter sets result in the same model performance, is directly addressed by GLUE procedures (Beven, 1993, 2006).

Our aim is to quantify the main salt sources in a lowland polder catchment area, and particularly the contribution of preferential seepage via boils. We used a probabilistic transient water and salt balance model based on end-member mixing principles to simulate two years of chloride concentration and discharge measurements at the polder catchment outlet. By applying the GLUE framework, we were able to obtain an estimate of the uncertainty in source contribution caused by the model equifinality and the uncertainty in the data. Using this model we calculated the effects of different scenarios involving climate change and adaptive strategies on the salt concentrations in the polder's surface waters.

\section{Material and methods}

\section{1 “Noordplas Polder" study area}

The study area is a typical lowland catchment area in a deep polder in the west of the Netherlands: Noordplas Polder (latitude $52^{\circ} 04^{\prime} \mathrm{N}$, longitude $04^{\circ} 34^{\prime} \mathrm{E}$ ) (Fig. 2). It covers $37 \mathrm{~km}^{2}$, of which $86 \%$ is agricultural land (arable farming $62 \%$; pasture $24 \%$ ) and $14 \%$ is urban area. This former lake was reclaimed in different phases in the period 1750-1850 AD (Schultz, 1992). Its present mean soil surface level is about $-5 \mathrm{~m}$ m.s.l. (mean sea level).

Geohydrologically, a $6 \mathrm{~m}$ to $9 \mathrm{~m}$ thick top-layer of Holocene peat, loam and clay deposits with low hydraulic conductivity lies above a sandy aquifer of Pleistocene aeolian and fluvial sediments with high hydraulic conductivity (Fig. 1). The hydraulic head difference between this upper aquifer and the surface water (approximately $1.5 \mathrm{~m}$ ) causes a permanent upward groundwater seepage flux in the entire polder area. The Holocene confining layer is partly intersected by a network of sandy paleochannel belts caused by erosion by tidal channels during the Holocene (van der Valk, 
1996; Berendsen and Stouthamer, 2000; Hijma et al., 2009). These are in direct contact with the upper aquifer and reduce the thickness of the confining clay layer. They act as preferential pathways for water flow and salt transport (Fig. 1). Besides these forms of seepage, groundwater from the upper aquifer also enters the surface water via boils (Fig. 1). The location of the sandy paleochannel belts and the known boils in the Noordplas Polder are shown in Fig. 2.

The polder is enclosed by dikes for protection against flooding. The surface water level in the Noordplas Polder is maintained at a nearly constant level of about $-6.2 \mathrm{~m}$ m.s.l. because of the agricultural requirements. Excess water is pumped out into the "boezem" (Fig. 1), which is a regional surface water system at a higher elevation $(-0.6 \mathrm{~m}$ m.s.1.) through which excess polder water is transported to the sea (van de Ven, 2003). During dry periods, relatively fresh water from the "boezem" is admitted to the polder at inlets (Fig. 1) in order to maintain surface water levels and decrease the surface water salinity in the polder by flushing. However, since this "boezem" water is a mix of fresh water from the River Rhine and water pumped from other deep polders, its salinity may also be elevated during dry periods. Five major inlet locations of "boezem" water are managed by the Water Board Rijnland, whereas many small inlets are controlled by farmers.

The major flow routes of water and salt entering or leaving the polder are shown in Fig. 1. Water enters the polder via precipitation, three types of groundwater seepage and the inlet of "boezem" water, and it leaves the polder via evapotranspiration and the pumping stations. The major part of the precipitation surplus and seepage is temporarily stored in the subsoil as soil water or groundwater before it is discharged. Groundwater is drained by subsurface drains and surface drainage in open ditches. Ditches collect the water from subsurface tile drainage and the excess water is transported through small canals to the pumping stations. The spacing of the tile drainage network is $10-20 \mathrm{~m}$ and the most common drainage depth is $1.2 \mathrm{~m}$ below soil surface. The long-term mean annual precipitation and potential evapotranspiration (Makkink, 1957) are $916 \mathrm{~mm}$ and $615 \mathrm{~mm}$, respectively. The total mean annual volume of water that is pumped out of the polder is as much as $925 \mathrm{~mm}$. The large difference between precipitation surplus and polder water discharge indicates the significant contribution from seepage and admitted "boezem" water to the polder discharge.

\subsection{Monitoring water and salt fluxes}

The groundwater and surface water monitoring programme in Noordplas Polder aimed to quantify daily water and salt fluxes into and out of the polder. The monitoring network is shown in Fig. 2 and a summary of the monitoring activities is given in Table 1. The most dynamic fluxes in Noordplas Polder are precipitation and evapotranspiration and the water and salt fluxes pumped out of the polder (De Louw et al.,
2010). These fluxes could be measured relatively accurately on a daily to weekly basis. Multiplying the total daily pumping time with the pumping capacity gives the daily discharge volume of the polder water. The pumping water was sampled automatically with a discharge-proportional frequency to obtain discharge weighted chloride concentrations and to determine the chloride loads out of the polder. The samples were mixed automatically to one bulk sample, stored in a refrigerator in the field and collected every 3 to 7 days, and analyzed in the laboratory for chloride. Multiplying the analyzed discharge weighted chloride concentration by the discharged volume of polder water resulted in the total chloride load pumped out of the polder for every 3 to 7 days. Daily precipitation was measured at two locations with a tipping bucket rain gauge. Daily sums of the potential reference crop evapotranspiration $\left(\mathrm{ET}_{\mathrm{mak}}\right)$ were calculated according to Makkink (1957) from data of the Royal Netherlands Meteorological Institute (KNMI), i.e., the KNMI sta-

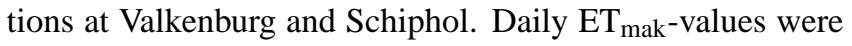
multiplied by a crop factor (Feddes, 1987) and weighted by land use.

Water and salt fluxes into the polder via seepage and the admission of "boezem" water are much more uncertain than the above mentioned balance terms. The five main inlets controlled by the water board were only measured incidentally and the volume of admitted "boezem" water at the small inlets controlled by the farmers is unknown. From the management practices of the inlets it is clear that much more "boezem" water is admitted in summer than in winter. Upward groundwater flow from the upper aquifer in the form of diffuse and paleochannel seepage cannot be measured directly (see Cirkel et al., 2010; Keery et al., 2007; Surridge et al., 2005; Murdoch and Kelly, 2003; Kishel and Gerla, 2002). However, the driving force of these seepage fluxes, the head difference between the upper aquifer and phreatic water levels, was accurately measured bi-weekly at 14 clusters of monitoring wells (see Fig. 2). Each cluster consisted of one monitoring well in the upper aquifer, 2 to 4 groundwater wells (in total 48) and a gauge in the ditch for surface water level observations. Groundwater level fluctuations were measured bi-weekly in the 48 groundwater wells to quantify the process of groundwater storage and drainage. A reliable estimate of total boil fluxes could not be made because the total number of boils is not known. Although 54 boils were found during field inventories (De Louw et al., 2010), we are sure that this is only a small part of the total number of boils in the polder. As boils are rather small, concentrated and mainly underwater phenomena, they are hard to find, especially in the larger and deeper canals. At 15 boils we were able to measure the boil flux, which varied between 0.5 and $100 \mathrm{~m}^{3} \mathrm{~d}^{-1}$ (De Louw et al., 2010). Although this gave us a better picture about individual boil fluxes and the variation between boils, the total number of boils is unknown and therefore the total boil flux in the polder. Chloride concentrations of the different seepage types were taken from De Louw 
Table 1. Summary of monitoring data of Noordplas Polder for period 1 August 1999 up to 1 August 2001.

\begin{tabular}{|c|c|c|c|c|c|c|c|c|c|}
\hline & Frequency & $\begin{array}{r}\text { No. of } \\
\text { locations }\end{array}$ & Unit & Average & Median & Std. & Min. & Max. & $\begin{array}{r}\text { Observations/ } \\
\text { location }\end{array}$ \\
\hline \multicolumn{10}{|c|}{ Quantitative } \\
\hline Precipitation & daily & 2 & $\mathrm{~mm} \mathrm{~d}^{-1}$ & 2.93 & 0.76 & 4.19 & 0 & 40.28 & 731 \\
\hline Evapotranspiration & daily & 1 & $\mathrm{~mm} \mathrm{~d}^{-1}$ & 1.54 & 1.09 & 1.34 & 0 & 5.42 & 731 \\
\hline Polder water discharge & daily & 2 & $\mathrm{~mm} \mathrm{~d}^{-1}$ & 2.53 & 1.66 & 2.51 & 0.51 & 18.30 & 731 \\
\hline Main inlets & incidental & 5 & $\mathrm{~mm} \mathrm{~d}^{-1}$ & - & - & - & - & - & - \\
\hline Small inlets & none & 150 & - & - & - & - & - & - & - \\
\hline Head upper aquifer & bi-weekly & 14 & $\mathrm{~m}+h_{\mathrm{s}}$ & 1.54 & 1.51 & 0.38 & 0.99 & 2.16 & 48 \\
\hline Groundwater level & bi-weekly & 48 & $\mathrm{~m}+h_{\mathrm{s}}$ & 0.42 & 0.38 & 0.40 & -0.69 & 1.84 & 48 \\
\hline Surface water level $\left(h_{\mathrm{s}}\right)$ & bi-weekly & 14 & m m.s.l. & -6.37 & -6.42 & 0.41 & -7.65 & -5.46 & 48 \\
\hline \multicolumn{10}{|c|}{ Chloride concentration } \\
\hline Precipitation & once & 1 & $m g 1^{-1}$ & 12 & - & - & - & - & 1 \\
\hline $\begin{array}{l}\text { Weighted Cl-conc. } \\
\text { polder water discharge }\end{array}$ & every $3-7$ days & 2 & $\mathrm{mg} 1^{-1}$ & 446 & 464 & 179 & 110 & 741 & 172 \\
\hline Total salt load & every $3-7$ days & 2 & $\mathrm{mg} \mathrm{l}^{-1}$ & 31.8 & 27.5 & 14.5 & 14.9 & 140 & 172 \\
\hline Inlet water in winter & monthly & 4 & $\mathrm{mg} \mathrm{l}^{-1}$ & 125 & 130 & 85 & 70 & 250 & 12 \\
\hline Inlet water in summer & monthly & 4 & $\mathrm{mg}^{-1}$ & 245 & 220 & 160 & 100 & 500 & 12 \\
\hline Boils & once & 49 & $\mathrm{mg} \mathrm{l}^{-1}$ & 1100 & 1300 & 638 & 337 & 2850 & 1 \\
\hline Paleochannel seepage & twice & 3 & $\mathrm{mg} \mathrm{l}^{-1}$ & 592 & - & - & 438 & 675 & 2 \\
\hline Diffuse seepage & twice & 11 & $\mathrm{mg}^{-1}$ & 117 & 95 & 96 & 33 & 281 & 2 \\
\hline
\end{tabular}

et al. (2010). The chloride concentration of the upper aquifer in areas with and without paleochannel belts in the confining layer was taken as representative for the paleochannel and diffuse seepage, respectively (Table 1). The chloride concentration was measured in the upper aquifer monitoring well at the 14 monitoring clusters from which 3 were located in areas with and 11 in areas without paleochannel belts (Fig. 2). The average chloride concentration in the upper aquifer for areas with paleochannel belts was $592 \mathrm{mg} / \mathrm{l}$ but only based on 3 locations (Table 1). In the 11 sites without paleochannel belts, the average chloride concentration was much lower at $117 \mathrm{mg} \mathrm{l}^{-1}$ (Table 1). The chloride concentration of boils was determined at 49 boils which showed a large variation between 337 and $2850 \mathrm{mg} \mathrm{l}^{-1}$ and an average of $1100 \mathrm{mg}^{-1}$ (Table 1). The larger boils intended to have higher concentrations (De Louw et al., 2010). As the three forms of groundwater seepage comes from below the confining layer (deeper than $7 \mathrm{~m}$ ) its composition will not change significantly due to seasonal variation in precipitation and evapotranspiration. This is confirmed by our monitoring data described in our previous work (De Louw et al., 2010). We analyzed the groundwater composition of the upper aquifer at two moments in the year (April and November) and the differences were less than $5 \%$.

\subsection{Modelling water and salt fluxes}

We combined a simple, fast End Member Mixing Approach (EMMA) model with an uncertainty estimation approach, the Generalized Linear Uncertainty Estimation GLUE (Beven and Binley, 1992), to quantify the daily water and salt fluxes and their uncertainties. This model links all the sources to the polder water discharge, concentrations and salt loads and incorporates the uncertainty in the sources. The different water and salt sources considered in the model are shown in Fig. 1. Since the three types of groundwater seepage, diffuse, paleochannel-, and boil seepage, differ with regard to seepage flux and chloride concentrations, they are considered as different end-members.

\subsubsection{Water balance}

The balance of the surface water network of the polder is given by:

$Q_{\text {pump }}(t)=Q_{\mathrm{b}}+Q_{\mathrm{a}}(t)+Q_{\mathrm{grw}, i}(t)$

$Q_{\text {pump }}\left(L^{3} \cdot T^{-1}\right)$ is the pumped volume from the polder into the "boezem", $Q_{\mathrm{b}}\left(L^{3} \cdot T^{-1}\right)$ is the seepage through boils directly into the surface water network, $Q_{\mathrm{a}}\left(L^{3} \cdot T^{-1}\right)$ is the admission of "boezem" water into the polder, and $Q_{\mathrm{grw}, i}$ $\left(L^{3} \cdot T^{-1}\right)$ is the groundwater flow into the surface water network. Because the pumps maintain a constant surface water 
level, we disregarded surface water storage changes. Since the majority of boils occur in ditches (De Louw et al., 2010) boil seepage, $Q_{\mathrm{b}}$ is assigned directly to the surface water network. Its flux was assumed to be constant because its driving force, the head difference between the first aquifer and the surface water level, remains relatively constant (De Louw et al., 2010). We distinguished different constant water admission fluxes from the "boezem" during the winter, $Q_{\mathrm{a} \text {, w }}$ $\left(L^{3} \cdot T^{-1}\right)$, and the summer, $Q_{\mathrm{a}, \mathrm{s}}\left(L^{3} \cdot T^{-1}\right)$. Infiltration (or leakage) from the higher situated "boezem" into the polder is not considered as a separate balance term because it has no significant contribution to the total water balance $(\ll 1 \%)$ due to the small area of "boezem" where such infiltration takes place. To account for the effects of paleochannel belts on the seepage water and salt flux we calculated the groundwater flux into the surface water network $\left(Q_{\mathrm{grw}, i}\right)$ separately for the area with paleochannel belts in the Holocene confining layer $(i=\mathrm{pch})$ and for the rest of the polder $(i=d)$.

In lowland catchments with free drainage, the transport of solutes is governed by the active extent of the drainage system (Carluer en Marsily, 2004; Wriedt et al., 2007; Tiemeyer et al., 2007; Molenat et al., 2008; van der Velde et al., 2009). In polders, however, groundwater levels and discharge are controlled by a totally artificial drainage network, and surface water levels are regulated by pumps and the admission of "boezem" water. Therefore, the active drainage system of a polder remains constant and its discharge storage relationship for a single field can be set as representative for the entire catchment. The groundwater flux towards the surface water network $Q_{\mathrm{grw}, i}\left(L^{3} \cdot T^{-1}\right)$, is derived by a separate water balance of the groundwater reservoir. Seepage and precipitation are temporarily stored in the subsoil causing the groundwater level to rise. Groundwater levels decline due to the drainage of groundwater and evapotranspiration. The water balance of the groundwater reservoir is given by:

$$
\begin{aligned}
n_{\mathrm{dr}} & \frac{\mathrm{d} h_{\mathrm{grw}, i}(t)}{\mathrm{d} t}=\frac{\mathrm{d} s_{\mathrm{grw}, i}(t)}{\mathrm{d} t} \\
& =P(t)-\mathrm{ET}(t)+q_{\mathrm{s}, i}(t)-q_{\mathrm{ditch}, i}(t)-q_{\mathrm{dr}, i}(t)
\end{aligned}
$$

With $n_{\mathrm{dr}}(-)$ the drainable porosity, $h_{\mathrm{grw}}(L)$ the average groundwater level, $s_{\text {grw }}(L)$ the total groundwater storage in the saturated and unsaturated zone, $P\left(L \cdot T^{-1}\right)$ the precipitation rate, ET $\left(\mathrm{L} \cdot \mathrm{T}^{-1}\right)$ the evapotranspiration rate, $q_{\mathrm{s}, i}$ $\left(L \cdot T^{-1}\right)$ the seepage flux rate, and $q_{\mathrm{ditch}}\left(L \cdot T^{-1}\right)$ and $q_{\mathrm{dr}}$ $\left(L \cdot T^{-1}\right)$ the groundwater flow rate towards ditches and tile drains, respectively. The seepage flux rates, $q_{\mathrm{s}, i}\left(L \cdot T^{-1}\right)$, (diffuse seepage, $i=d$, and paleochannel seepage, $i=\mathrm{pch}$ ) are derived by Darcy's law:

$q_{\mathrm{s}, i}(t)=\frac{H_{\mathrm{Aq}}-h_{\mathrm{grw}, i}(t)}{r_{i}}$

With $H_{\mathrm{Aq}}(L)$ the constant hydraulic head in the first aquifer. Note that differences in seepage fluxes between locations with and without paleochannels, are only caused by a different hydraulic resistance of the Holocene confining layer, $r(T)$. As the confining layer consists of different lithological layers $n$ with thickness $d_{n}(L)$ and vertical saturated hydraulic conductivity $k_{\mathrm{v}, n}\left(L \cdot T^{-1}\right)$ the hydraulic resistance of the Holocene confining layer, $r(T)$ is defined as:

$r_{i}=\sum_{n} \frac{d_{n}}{k_{\mathrm{v}, n}}$

The groundwater flow rate towards ditches, $q_{\mathrm{ditch}}\left(L \cdot T^{-1}\right)$, and tile drains, $q_{\mathrm{dr}}\left(L \cdot T^{-1}\right)$, are derived using the drainage formula of Hooghoudt (1940). We assumed there was no infiltration from surface water during dry periods, since these infiltration fluxes can be neglected compared to the total groundwater drainage flux because of the limited period in which such infiltration takes place, the large ditch distances $(>100 \mathrm{~m})$ and the small area of surface water $(<2 \%)$. There is no surface water infiltration via subsurface drains because the drains are always situated above the ditch water level.

$q_{\mathrm{ditch}, i}(t)=\left(h_{\mathrm{grw}, i}(t)-h_{\mathrm{s}}\right) \frac{4 k D}{l_{\mathrm{s}}^{2}}$ for $h_{\mathrm{grw}, i}>h_{\mathrm{s}}$
$q_{\mathrm{ditch}, i}(t)=0$ for $h_{\mathrm{grw}, i}<h_{\mathrm{s}}$

$q_{\mathrm{dr}, i}(t)=\left(h_{\mathrm{grw}, i}(t)-h_{\mathrm{dr}}\right) \frac{4 k D}{l_{\mathrm{dr}}^{2}}$ for $h_{\mathrm{grw}, i}>h_{\mathrm{dr}}$ $q_{\mathrm{dr}, i}(t)=0$ for $h_{\mathrm{grw}, i}<h_{\mathrm{dr}}$

With saturated hydraulic conductivity $k\left(L \cdot T^{-1}\right)$, layer thickness, $D(L)$, surface water level in ditch $h_{\mathrm{s}}(L)$, drainage level $h_{\mathrm{dr}}\left(L+h_{\mathrm{s}}\right)$ and spacing between parallel subsurface drains, $l_{\mathrm{dr}}(L)$, and ditches $l_{\mathrm{S}}(L)$. Because the upper $5 \mathrm{~m}$ of the confining layers with and without paleochannel belts do not differ significantly from each other (De Louw et al., 2010 ), we used one $k D$ value for both geohydrological situations.

Finally, the total groundwater flux towards the surface water network is calculated by:

$$
Q_{\mathrm{grw}, i}(t)=A_{i}\left(q_{\mathrm{ditch}, i}(t)+q_{\mathrm{dr}, i}(t)\right)
$$

With $A_{i}$ the surface area of locations with $(i=\mathrm{pch})$ and without $(i=d)$ paleochannel belts.

\subsubsection{Salt balance}

The salt balance equation is obtained by multiplying the fluxes of the water balance equation (Eq. 1) with the concentration corresponding to the fluxes. The solute balance of the surface water is given by:

$$
\begin{aligned}
& Q_{\mathrm{pump}}(t) \cdot c_{\mathrm{pump}}(t)=Q_{\mathrm{b}} \cdot c_{\mathrm{b}}+Q_{\mathrm{a}, \mathrm{w}} \cdot c_{\mathrm{a}, \mathrm{w}}+Q_{\mathrm{a}, \mathrm{s}} \\
& \cdot c_{\mathrm{a}, \mathrm{s}}+Q_{\mathrm{grw}, d}(t) \cdot c_{\mathrm{grw}, d}(t)+Q_{\mathrm{grw}, \mathrm{pch}}(t) \cdot c_{\mathrm{grw}, \mathrm{pch}}(t)
\end{aligned}
$$

With $c_{\text {pump }}\left(M \cdot L^{-3}\right)$ the concentration of the water pumped from the polder. The boils have a constant concentration denoted by $c_{\mathrm{b}}\left(M \cdot L^{-3}\right)$. The concentration of admission water 
from the "boezem", $c_{\mathrm{a}}\left(M \cdot L^{-3}\right)$, is assumed to have different constant values for the winter, $c_{\mathrm{a}, \mathrm{w}}\left(M \cdot L^{-3}\right)$, and the summer, $c_{\mathrm{a}, \mathrm{s}}\left(M \cdot L^{-3}\right)$.

The concentration of the groundwater flux, $c_{\mathrm{grw}}\left(M \cdot L^{-3}\right)$, is derived from the mass balance of the groundwater reservoir for the area with $(i=\mathrm{pch})$ and without $(i=d)$ paleochannel belts (Eq. 9). We assumed that chloride is completely mixed in the top soil (Rinaldo et al., 2006) resulting in an average concentration for the groundwater reservoir. It is expressed by:

$c_{\mathrm{grw}, i}(t)=\frac{m_{i}(t)}{s_{\mathrm{grw}, i}(t)}$

With $m_{i}\left(M \cdot L^{-2}\right)$ the total salt mass density, which can be derived from the salt mass balance of the groundwater reservoir:

$$
\begin{aligned}
\frac{\mathrm{d} m_{i}(t)}{\mathrm{d} t} & =P(t) \cdot c_{\mathrm{p}}+q_{\mathrm{s}, i}(t) \cdot c_{\mathrm{s}, i} \\
& -\left(q_{\mathrm{ditch}, i}(t)+q_{\mathrm{dr}, i}(t)\right) \cdot c_{\mathrm{grw}, i}(t)
\end{aligned}
$$

We assumed that rainfall has a constant concentration, $c_{\mathrm{p}}$, and that also the diffuse and paleochannel seepage fluxes have constant concentrations: $c_{\mathrm{s}, \mathrm{d}}$ and $c_{\mathrm{s} \text {,pch }}$ (De Louw et al., 2010).

\subsubsection{GLUE application}

The calculation speed of our model allowed us to use the GLUE method (Beven and Binley, 1992) to find parameter sets that yielded good agreement with the measurements. This method is based on the idea that the model does not have one optimal parameter set but a collection of parameter sets, each of which perform equally well in reproducing the observations (Freer et al., 1996; Pappenberger et al., 2005; Roux and Dartus, 2006). These parameter sets are derived by Monte Carlo simulation of the model equations, randomly sampling parameters from prior distributions. A calculated "goodness-of-fit criterion" (likelihood) based on predicted and observed responses, evaluates how well a particular parameter combination simulates the system. Cut-off criteria divide the parameter space into "behavioural" and "non-behavioural" sets. Behavioural parameter sets are those which perform acceptable on the basis of available data and knowledge. For each time step, the modelled output is characterized by the distribution produced by the behavioural runs. As is common practice in GLUE applications, the median represents the output estimate (Blasone et al., 2008a) and the uncertainty ranges can be defined by the standard deviation, percentiles or minimum and maximum values of the distribution.

To reproduce enough behavioural runs to reconstruct complete and smooth behavioural parameter distributions we carried out $5.10^{8}$ Monte Carlo simulations, sampling from uniform prior distributions of 17 model input parameters. The
Monte Carlo simulations were carried out with two different prior distribution ranges (Table 2). To minimize the uncertainty of the simulated water and salt fluxes we used ranges that were as small as possible (indicated by GA-A in Table 2), which were mainly based on our measurements (summarized in Table 1). The size of the ranges is a direct representation of the uncertainty of the measurements, which is influenced by factors such as type of parameter, type of measurement, number of locations or observations, and variation of the data. We applied broader ranges for the sensitivity analysis to determine the sensitivity of the parameters within the full range of plausible values for the water system under consideration (indicated by GA-B in Table 2). The use of 2 different prior parameter ranges gave also the opportunity the compare the model output uncertainty for a situation with (small ranges) and without (broad ranges) the availability of measurements. We did not include uncertainty in precipitation and evaporation since they could be measured relatively accurately.

The model was applied for a period of 791 days of polder water discharge, salt loads and concentration observations (1 August 1999-30 November 2001) of the Noordplas Polder. For each day the model calculates the total discharge by pumps, $Q_{\text {pump }}$, the concentration of the pumped water, $c_{\text {pump }}$, the total pumped chloride loads $L_{\text {pump }}$ and the average groundwater level $h_{\text {grw }}$. We compared these model responses with our measurements by calculating likelihoods (Table 3) for different time scales; daily to weekly (dyn), quarterly seasonally (season) and for the entire simulation period (tot). The Nash-Sutcliffe coefficient (NSC) (Nash and Sutcliffe, 1970) was used to evaluate the modelled $Q_{\text {pump }}$, $c_{\text {pump }}$ and $L_{\text {pump }}$ on daily to seasonal time scales:

$$
\mathrm{NSC}=1-\frac{\sum_{i=1}^{n}\left(o_{i}-p_{i}\right)^{2}}{\sum_{i=1}^{n}\left(o_{i}-\bar{o}\right)^{2}}
$$

With $o_{i}$ the observed and $p_{i}$ the predicted output value for time step $i$ and $\bar{o}$ the average observed value. We evaluated the total summed water and salt budgets, and average salt concentrations of the discharge water, for the entire simulation period ( $€($ tot $)$ ). The calculated groundwater level time series were behavioural when they fitted within the 10 and 90 percentiles of the 48 measured time series. The cut-off criteria for the different likelihoods are listed in Table 3. We analyzed the individual NSC's and determined the cutoff criteria which produced an equal number of behavioural runs to assign equal weight to the different NSC-likelihoods. Furthermore, we set the cut-off criteria by trial and error to fit most of our observations between the modelled uncertainty ranges and to keep these ranges as small as possible. The choices of the cut-off criteria are rather subjective and can be seen as the major shortcoming of such Monte Carlo based model evaluation method (Beven, 2006; Blasone et al., 
Table 2. Applied ranges of prior uniform distribution of sampled model input parameters for the different GLUE-analyses (GA).

\begin{tabular}{|c|c|c|c|c|}
\hline \multirow[b]{2}{*}{ Parameter } & \multirow[b]{2}{*}{ Name } & \multirow[b]{2}{*}{ Unit } & \multicolumn{2}{|c|}{ Parameter ranges for: } \\
\hline & & & $\begin{array}{l}\text { Modelling } \\
\text { water and } \\
\text { salt fluxes } \\
\text { (GA-A) }\end{array}$ & $\begin{array}{l}\text { Parameter } \\
\text { sensitivity and } \\
\text { uncertainty analysis } \\
\text { (GA-B, GA-C) }\end{array}$ \\
\hline \multicolumn{5}{|c|}{ Parameters that control incoming fluxes } \\
\hline$Q_{\mathrm{b}}$ & Boil seepage flux & $\mathrm{mm} \mathrm{d}^{-1}$ & $0-1.1$ & $0-1.1$ \\
\hline$Q_{\mathrm{a}, \mathrm{s}}$ & Admission flux of "boezem" water in summer & $\mathrm{mm} \mathrm{d}^{-1}$ & $0.1-1.0$ & $0-2.2$ \\
\hline$Q_{\mathrm{a}, \mathrm{w}}$ & Admission flux of "boezem" water in winter & $\mathrm{mm} \mathrm{d}^{-1}$ & $0-0.3$ & $0-2.2$ \\
\hline$r_{\mathrm{pch}}^{*}$ & Hydraulic resistance of confining layer with paleochannel belt & $\mathrm{d}$ & $500-1000$ & $1-1500$ \\
\hline & Hydraulic resistance of confining layer without paleochannel belt & $\mathrm{d}$ & $3000-6000$ & $1-10000$ \\
\hline$\ddot{H}_{\mathrm{Aq}}$ & Hydraulic head in upper aquifer & $\mathrm{m}+h_{\mathrm{s}}$ & $1.0-2.0$ & $0-2.5$ \\
\hline$A_{\text {pch }}$ & Area with paleochannel channel belts in confining layer & $\%$ & $0.12-0.22$ & $0.07-0.27$ \\
\hline \multicolumn{5}{|c|}{ Chloride concentration of incoming fluxes } \\
\hline$c_{\mathrm{b}}$ & Cl-conc. of boil seepage & $\mathrm{mg}^{-1}$ & $500-2500$ & $1-4000$ \\
\hline$c_{\mathrm{a}, \mathrm{s}}$ & Cl-conc of admitted "boezem" water in summer & $\mathrm{mg} 1^{-1}$ & $100-500$ & $1-500$ \\
\hline$c_{\mathrm{a}, \mathrm{w}}$ & Cl-conc of admitted "boezem" water in winter & $\mathrm{mg}^{-1}$ & $50-200$ & $1-500$ \\
\hline$c_{\mathrm{s}, \mathrm{pch}}$ & Cl-conc. of paleochannel seepage & $\mathrm{mg} 1^{-1}$ & $400-800$ & $1-1500$ \\
\hline$c_{\mathrm{S}, \mathrm{d}}$ & Cl-conc. of diffuse seepage & $\mathrm{mg} 1^{-1}$ & $50-250$ & $1-500$ \\
\hline \multicolumn{5}{|c|}{ Parameters that control gw-sw interaction } \\
\hline$k D^{*}$ & Transmissivity of confining layer & $\mathrm{m}^{2} \mathrm{~d}^{-1}$ & $0.1-10.0$ & $0.01-20.0$ \\
\hline$h_{\mathrm{dr}}$ & Level of subsurface drains & $\mathrm{m}+h_{\mathrm{s}}$ & $0-0.6$ & $0-1.0$ \\
\hline$l_{\mathrm{dr}}$ & Spacing between parallel subsurface drains & $\mathrm{m}$ & $10-30$ & $1-50$ \\
\hline$l_{\text {ditch }}$ & Spacing between parallel ditches & $\mathrm{m}$ & $100-200$ & $1-300$ \\
\hline$n_{\mathrm{dr}}$ & Drainable porosity & - & $0.05-0.15$ & $0.01-0.30$ \\
\hline
\end{tabular}

Ranges are based on data from a monitoring campaign (Table 1) and collected field data except for * see Weerts (1996).

Table 3. "Goodness-of-fit" criteria (likelihoods) and cut-off criteria. Model runs are only assigned as behavioural when they satisfy all the individual goodness-of-fit criteria.

\begin{tabular}{llll}
\hline Likelihood & $\begin{array}{l}\text { Cut-off criterion: } \\
\text { behavioural when }\end{array}$ & Likelihood & $\begin{array}{l}\text { Cut-off criterion: } \\
\text { behavioural when }\end{array}$ \\
\hline NSC $Q_{\text {pump }}($ dyn) & $>0.55$ & NSC $Q_{\text {pump }}$ (season) & $>0.90$ \\
NSC $c_{\text {pump }}($ dyn) & $>0.55$ & NSC $c_{\text {pump }}$ (season) & $>0.80$ \\
NSC $L_{\text {pump }}($ dyn $)$ & $>0.25$ & NSC $L_{\text {pump }}$ (season) & $>0.85$ \\
$h_{\text {grw }}($ dyn) & $>10$-percentile AND & $€($ tot $)-Q_{\text {pump }}, €($ tot $)-c_{\text {pump }}$, & $<5 \%$ \\
& $<90$-percentile & $€($ tot $)-L_{\text {pump }}$ & \\
\hline
\end{tabular}

dyn $=$ measurement time scale (days for $Q_{\text {pump }}, 3$ to 7 days for $c_{\text {pump }}$ and $L_{\text {pump }}$, bi-weekly for $h_{\text {grw }}$ ), season $=$ quarterly seasonally, tot $=$ entire simulation period.

2008a). A strong characteristic of the applied GLUE method is the use of likelihoods that evaluate different elements of the water system (discharge, solute concentration and loadand groundwater level) at different time scales. Model runs are only assigned as behavioural when they satisfy all the individual likelihood criteria.

Hydrol. Earth Syst. Sci., 15, 2101-2117, 2011

\subsubsection{Parameter sensitivity and uncertainty analysis}

Apart from aiming at a correct simulation of the observed water and salt fluxes at the polder catchment outlet, we were interested in the sensitivity of the different parameters to the model results. As almost all model parameters are related to measurable parameters, a sensitivity analysis also provides important information for future field data acquisition 
to reduce measurement uncertainty and improve the model's reliability. Generally, two kind of sensitivity analysis can be distinguished: a global sensitivity and a local sensitivity analysis (Tiemeijer et al., 2007; Spear and Hornberger, 1980). With local techniques parameter interdependencies are ignored and were found to be unreliable for non-linear relationships between parameters and outputs which are typical for hydrological outputs (Tiemeyer et al., 2007; Muleta and Nicklow, 2005). Therefore, we used the above described GLUE method for a global sensitivity analysis where all parameters are varied at the same time. The global sensitivity of the parameters for the model output was determined in two ways. First, the global sensitivity of parameters for the total model behaviour was determined. We applied the GLUE method using the same cut-off criteria (Table 3) but with wider prior parameter ranges (indicated as GA-B, Table 2). In contrast with non-sensitive parameters which show uniform posterior distributions close to their prior distributions, the sensitive parameters show large deviations. The Kolmogorov D statistics for testing of differences in distributions was used as measure of the parameter sensitivity (van Huissteden et al., 2009; Roux and Dartus, 2006). The interdependencies of the model parameters were quantified by the determination of correlation between all behavioural parameter combinations (expressed in $R^{2}$ ). Strong interdependencies (indicated by a large $R^{2}$ ) also revealed which parameters were sensitive to the total model response. Second, we tested the global sensitivity of the model parameters for the individual model output. We calculated $R^{2}$ between parameter values and model output errors for total water volume, total salt load, and mean salt concentration for the entire simulation period ( $€\left(\right.$ tot)). In addition, $R^{2}$ was calculated between parameter values and model errors on measurement time scale ( $€($ dyn)). To focus on this short time scale, for this analysis we used only behavioural parameter sets with absolute errors in the total water and salt balance and mean concentrations which were smaller than $5 \%$. This GLUE analysis is indicated as GA-C.

\subsection{Scenario analysis}

The model was used to calculate the effects of future changes on surface water salinization. We applied all the behavioural parameter sets retrieved by the GLUE analysis to incorporate parameter and model uncertainty into the predictions. We then worked out three scenarios in detail. Scenario 1 illustrates the effect of the so-called $w^{+}$climate scenario for the year 2100, formulated by the Royal Netherlands Meteorological Institute KNMI (van den Hurk et al., 2006). This is the driest of four climate scenarios which are frequently used for analyses in the Netherlands. Compared to the present situation, it is characterized by greater precipitation in winter, and less precipitation and higher evaporation in the summer due to higher temperatures. It is expected that sea-level rise and changes in precipitation surplus will also reduce fresh water availability for admission into the deep polders. Admission water originates from one of the major Dutch rivers (here the River Rhine), and this may become unsuitable if future sea-level rise and decrease of river discharge cause sea water intrusion further upstream on the river. In scenario 2 we calculated the effect of a $50 \%$ reduction of admitted "boezem" water in the summer. To compensate or even reduce the future increase of surface water salinity, it is worth investigating the effectiveness of mitigation measures. Because preferential seepage via boils is the dominant mechanism of salinization in deep Dutch polders (De Louw, et al., 2010), measures which reduce the contribution of boils should be effective in dealing with salinization. In scenario 3 , we demonstrate the effect of reducing the boil seepage flux by $30 \%$ and do not consider the practical implications of this measure.

\section{Results and discussion}

\subsection{Discharge, chloride concentrations and chloride loads}

The $5.10^{8}$ Monte Carlo simulations sampling from the prior parameter ranges (Table 2) and applying the cut-off criteria from Table 3 resulted in 59630 behavioural simulations (GA-A). The entire ensemble of the behavioural model output of polder water discharge, salt concentration and salt loads are shown in Fig. 3, together with the observed time series. The daily observed polder water discharge, both peak and base flow, was simulated well with small uncertainty ranges. However, some of the observed discharge peaks during the summer period are underestimated. This may be due to ignoring the unsaturated zone in our model concept (e.g. development of cracks, unsaturated overland flow). Although the range of the modelled chloride concentrations was larger than the range of the modelled discharge, the observed dynamics were well represented by the calculated median chloride concentration. Note that the blocked shape of the measured chloride concentration and load is caused by the collection of discharge weighted water samples every 3 to 7 days. For comparison the modelled chloride concentration and load were also converted to average values. Both polder water discharge and salt concentration are highly variable in time and show opposite responses. Low concentrations were found in periods of high discharge due to dilution by the discharge of shallow groundwater and rainfall. Concentrations gradually increased during dry periods when the contribution of drained shallow groundwater decreases and the input of salt sources becomes more dominant.

Compared with polder water discharge and chloride concentrations, the observed chloride loads showed an attenuated variation as a function of time. For $90 \%$ of the time, the measured chloride loads were between 20 and $50 \mathrm{td}^{-1}$. Chloride loads never dropped to less than $15 \mathrm{td}^{-1}$, which 


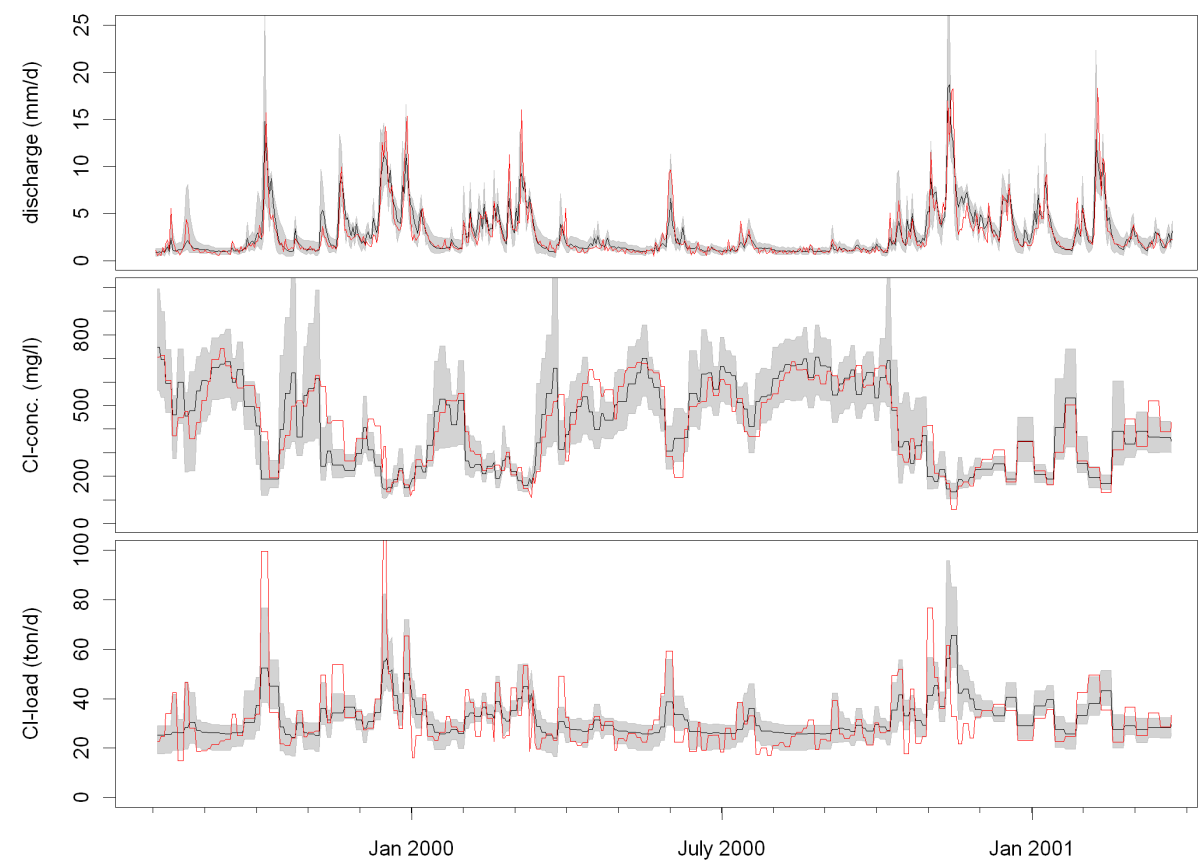

Fig. 3. Observed (red) and modelled (median, black) polder water discharge, chloride concentration of discharge water and total chloride loads. Grey area indicates the uncertainty of the model output estimate characterized by the minimum and maximum of the entire ensemble of 59630 behavioural simulations (GLUE analysis GA-A).

indicates a significant saline source throughout the year, even in dry periods with low discharges. Remarkably, major peaks of chloride loads coincided with relatively low chloride concentrations, as they occurred during peak flows (Fig. 3). Heavy rainfall events probably mobilized "older" water containing chloride. This chloride originates from seepage which is mixed with infiltrated rainwater and temporarily stored in the groundwater reservoir. The simulations of chloride load dynamics showed less satisfactory results than those of discharge and chloride concentration. This is what we expected, because chloride loads are derived by the multiplication of water discharges and their chloride concentrations, hence errors in both quantities will be expressed in the simulated chloride loads. The modelled peaks of chloride loads were underestimated and during base flow the modelled chloride loads were slightly larger than observed. Considering that total chloride loads are simulated well by applying the cut-off criterion $€($ tot $)-L_{\text {pump }}$ that allows a total salt balance error of $5 \%$, we think the underestimated simulated dynamics of chloride loads can be explained by shortcomings in the model concepts that control the storage and discharge of chloride. First, we neglected storage of chloride in the surface water. During dry periods, surface water chloride concentrations increase but transport velocities to the pumps are small due to small discharges. Consequently, new rain showers will accelerate the transport of stored chloride, resulting in elevated chloride loads. Second, the assumption that boils directly discharge into the surface water may have noticeable consequences, since this chloride is therefore not stored in the mixing reservoir like chloride from diffuse and paleochannel seepages, but is instantly released into the surface water without any temporal variation.

\subsection{Quantification of salt sources}

In Fig. 4, the cumulative probability distribution function for each source derived from all the behavioural simulations is shown. The dominant water source is precipitation. Precipitation surplus $(P-\mathrm{ET})$ contributes more than $55 \%$ to the total polder water discharge. Since we did not vary the precipitation and evapotranspiration fluxes, the range found for this contribution is exclusively the result of the applied cut-off criterion $€$ (tot) $-Q_{\text {pump }}$ of Table 2 that allows a water balance error of $5 \%$. Despite its domination of water input, the contribution of precipitation to the total salt load is small due to its low concentration. The contribution of admitted "boezem" water to the total salt load is less than $1 \%$ in the winter and about $6 \%$ (standard deviation $\pm 2.3 \%$ ) in the summer. Salt loads derived from paleochannel seepage are much larger $(18 \% \pm 5.7 \%)$ than those derived from diffuse seepage $(4 \% \pm 1.6 \%)$, due to the elevated chloride concentration of paleochannel seepage. However, the model results show that the most important salt source is upward groundwater flow through boils, with an average contribution of $66 \%( \pm 7.2 \%)$ to the total salt load, despite the fact that they contribute only $15 \%( \pm 4.7 \%)$ to the polder water 

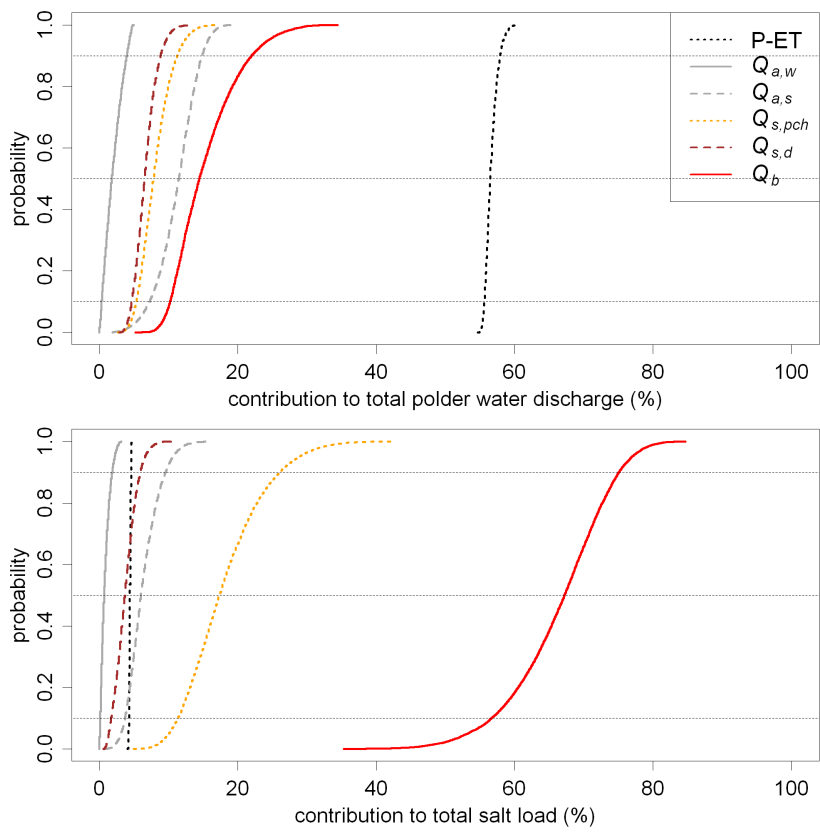

Fig. 4. Cumulative probability distribution function for the contribution of different sources to the total polder water discharge and total salt load of the polder (in \%) (GLUE analysis GA-A).

discharge. In $95 \%$ of the behavioural simulations, boils contributed more than $50 \%$ to the total salt load of the polder.

Upward groundwater flow from the upper aquifer via boils and via sandy paleochannel belts in the Holocene confining layer are both forms of preferential seepage. The area where they occur is small compared to the total polder area, as is apparent from Fig. 2. Our model results show that these forms of preferential seepage together contribute about $84 \%( \pm 7.2 \%)$ to the total salt load of the polder, and this is primarily the consequence of the high chloride concentrations of water discharged in this way. The average calculated behavioural value is about $1400 \mathrm{mg} \mathrm{l}^{-1}\left( \pm 320 \mathrm{mg} \mathrm{l}^{-1}\right)$ for boils, which is more than two times that of paleochannel seepage (700 $\mathrm{mg} \mathrm{l}^{-1}$ ) and much higher than that of diffuse seepage $\left(170 \mathrm{mg}^{-1}\right)$ or the average concentration of inlet water $\left(150 \mathrm{mgl}^{-1}\right)$. The concentration difference between the three seepage types can be explained by the upconing mechanism proposed by De Louw et al. (2010). Higher seepage fluxes result in upconing of deeper groundwater. Since the salinity of groundwater increases with increasing depth in the Noordplas Polder, higher seepage fluxes are associated with higher chloride concentrations (Fig. 1).

\subsection{Parameter uncertainty and sensitivity}

The posterior parameter distributions of GLUE analysis GA$B$ with wider prior parameter ranges than GA-A are shown in Fig. 5. The large variation in behavioural parameter value indicates that there is strong equifinality. This equifinality can be reduced by narrowing the ranges of the prior parameter distribution based on measurements or the literature. Table 4 shows that smaller prior ranges (GA-A) also lead to smaller uncertainty ranges in the model output. This illustrates that both model input- as well as model output uncertainty can be reduced by incorporating field measurements. Table 4 also shows that daily to weekly measurements of polder water discharge, weighted concentration and groundwater levels are essential for deriving an adequate set of behavioural parameters to yield a correct simulation of salt and water fluxes. Ignoring the dynamics of the system responses leads to an enormous increase in uncertainty of the model output and source distribution (GA-C). Note that despite the large uncertainty in the model output due to leaving out the daily to weekly measurements, the total water and salt balance errors are still less than $5 \%$.

To improve the reliability of the modelled water and salt fluxes and concentrations, field data can be best collected for those parameters to which the results are sensitive. A strong difference between the posterior behavioural distribution and the prior uniform distribution reveals which parameters can be considered sensitive (Fig. 5), and this is indicated by large D-statistics (Table 5). Largest D-statistics were calculated for boil seepage $Q_{\mathrm{b}}$, admission of "boezem" water in the summer $Q_{\mathrm{a}, \mathrm{s}}$ and winter $Q_{\mathrm{a}, \mathrm{w}}$. They have a maximum value above which no behavioural runs were found (Fig. 5). It is not surprising that these water balance terms also show a large correlation with the total water balance error (Table 5). Table 5 shows that total chloride load and mean concentration of the polder water are dominantly determined by boil seepage $\left(Q_{\mathrm{b}}\right)$ and its concentration $\left(c_{\mathrm{b}}\right)$ as indicated by a large calculated $R^{2}$. Behavioural values of $c_{\mathrm{b}}$ show a clear minimum (Fig. 5), indicating that boils must have higher chloride concentrations. Furthermore, the large sensitivity of $Q_{\mathrm{b}}$ and $c_{\mathrm{b}}$ is shown by their strong interdependency (Fig. 6). The fact that some sensitive parameters are correlated with each other can be used to reduce model inputand output uncertainty. Considering that the total boil flux $Q_{\mathrm{b}}$ is the parameter that is the most difficult to measure, its uncertainty can be reduced by increasing the reliability of the parameters most strongly correlated to it, $c_{\mathrm{b}}$ and $Q_{\mathrm{a}, \mathrm{s}}$, which can be measured more easily (Fig. 6).

The dynamics of the model output are mainly determined by the parameters that control the interaction between groundwater storage and drainage. Some of these parameters show large D-statistics, indicating a large sensitivity for the total system behaviour, but they do not have an impact on the total modelled water and salt volumes. Tile drainage spacing $l_{\mathrm{dr}}$ has the largest impact on the polder water discharge dynamics, whereas drainage level $h_{\mathrm{dr}}$ and ditch spacing $l_{\mathrm{ditch}}$ control the groundwater level and its fluctuations. Fluctuations in chloride concentration are mainly determined by drainable porosity $n_{\mathrm{dr}}$. 
Table 4. Uncertainty ranges for three GLUE analyses with different prior parameter distributions ranges and cut-off criteria. The uncertainty ranges are represented by the statistics of the entire ensemble of daily simulated discharge $Q$, concentration $C l$ and salt load $L$ and by the quantified source contribution to total polder water discharge and salt load in \%.

\begin{tabular}{|c|c|c|c|c|c|c|c|c|c|c|c|c|c|}
\hline \multicolumn{2}{|c|}{ GLUE analysis } & \multicolumn{4}{|c|}{ GA-A } & \multicolumn{4}{|c|}{ GA-B } & \multicolumn{4}{|c|}{ GA-C } \\
\hline \multicolumn{2}{|c|}{ Use } & \multicolumn{4}{|c|}{$\begin{array}{l}\text { Water and salt fluxes, } \\
\text { source contribution }\end{array}$} & \multicolumn{4}{|c|}{$\begin{array}{c}\text { Parameter sensitivity and } \\
\text { uncertainty analysis }\end{array}$} & \multicolumn{4}{|c|}{$\begin{array}{l}\text { Parameter sensitivity } \\
\text { and uncertainty analysis }\end{array}$} \\
\hline \multicolumn{2}{|c|}{$\begin{array}{l}\text { Prior parameter } \\
\text { ranges }\end{array}$} & \multicolumn{4}{|c|}{$\begin{array}{l}\text { Small ranges based on } \\
\text { measurements (Table 2) }\end{array}$} & \multicolumn{4}{|c|}{ Wide ranges (Table 2) } & \multicolumn{4}{|c|}{ Wide ranges (Table 2) } \\
\hline \multicolumn{2}{|c|}{ Cut-off criteria } & \multicolumn{4}{|c|}{ Table 3} & \multicolumn{4}{|c|}{ Table 3} & \multirow{2}{*}{\multicolumn{4}{|c|}{$\begin{array}{c}€(\text { tot })-Q_{\text {pump }}, €(\text { tot })-c_{\text {pump }} \\
€(\text { tot })-L_{\text {pump }}<5 \% \\
265641\end{array}$}} \\
\hline \multicolumn{2}{|c|}{ No of behaviourals } & \multicolumn{4}{|c|}{59630} & \multicolumn{4}{|c|}{2300} & & & & \\
\hline & & $\min$ & mean & stdev & $\max$ & $\min$ & mean & stdev & $\max$ & $\min$ & mean & stdev & $\max$ \\
\hline$Q$ & $\mathrm{~mm} \mathrm{~d}^{-1}$ & 1.8 & 2.8 & 0.4 & 3.8 & 1.5 & 2.7 & 0.4 & 4.0 & 0.2 & 2.7 & 1.4 & 53.1 \\
\hline $\mathrm{Cl}$ & $\mathrm{mg} \mathrm{l}^{-1}$ & 330 & 434 & 37 & 555 & 299 & 429 & 48 & 605 & 120 & 424 & 92 & 1619 \\
\hline$L$ & $\mathrm{td}^{-1}$ & 25.6 & 31.8 & 2.0 & 38.5 & 23.6 & 32.0 & 2.8 & 41.7 & 3.2 & 32.2 & 9.1 & 227.0 \\
\hline$P-\mathrm{ET}$ & $\%$ & 54.7 & 56.6 & 0.9 & 60.7 & 53.1 & 57.1 & 1.4 & 65.5 & 13.8 & 56.3 & 2.1 & 67.5 \\
\hline$Q_{\mathrm{a}, \mathrm{w}}$ & $\%$ & 0.0 & 2.0 & 1.3 & 5.0 & 0.0 & 6.7 & 4.6 & 28.8 & 0.0 & 10.1 & 7.7 & 38.8 \\
\hline$Q_{\mathrm{a}, \mathrm{s}}$ & $\%$ & 1.9 & 11.2 & 2.9 & 18.9 & 0.1 & 13.2 & 4.5 & 25.3 & 0.0 & 16.3 & 8.7 & 40.9 \\
\hline$Q_{\mathrm{s}, \mathrm{pch}}$ & $\%$ & 2.7 & 8.1 & 2.3 & 17.2 & 0.0 & 6.0 & 4.6 & 32.2 & 0.0 & 3.2 & 5.6 & 35.3 \\
\hline$Q_{\mathrm{s}, \mathrm{d}}$ & $\%$ & 2.9 & 6.7 & 1.6 & 13.8 & 0.0 & 4.5 & 3.1 & 19.7 & 0.0 & 2.6 & 4.8 & 62.4 \\
\hline$Q_{\mathrm{b}}$ & $\%$ & 5.2 & 15.4 & 4.7 & 34.4 & 0.3 & 12.5 & 7.6 & 38.8 & 0.0 & 11.3 & 7.5 & 39.2 \\
\hline$L_{P-\mathrm{ET}}$ & $\%$ & 4.1 & 4.4 & 0.1 & 4.7 & 3.9 & 4.5 & 0.3 & 9.6 & 1.0 & 4.5 & 0.5 & 15.4 \\
\hline$L_{\mathrm{a}, \mathrm{w}}$ & $\%$ & 0.0 & 0.9 & 0.7 & 3.2 & 0.0 & 6.4 & 6.2 & 49.2 & 0.0 & 10.1 & 11.0 & 77.5 \\
\hline$L_{\mathrm{a}, \mathrm{s}}$ & $\%$ & 0.7 & 6.4 & 2.3 & 16.3 & 0.0 & 9.5 & 7.0 & 46.5 & 0.0 & 15.2 & 12.6 & 100.0 \\
\hline$L_{\mathrm{s}, \mathrm{pch}}$ & $\%$ & 5.0 & 18.1 & 5.7 & 42.7 & 0.0 & 16.8 & 13.0 & 88.8 & 0.0 & 9.5 & 18.9 & 88.2 \\
\hline$L_{\mathrm{S}, \mathrm{d}}$ & $\%$ & 0.6 & 3.8 & 1.6 & 10.8 & 0.0 & 4.0 & 3.8 & 25.7 & 0.0 & 2.3 & 5.3 & 59.1 \\
\hline$L_{\mathrm{b}}$ & $\%$ & 35.3 & 66.4 & 7.2 & 84.7 & 0.7 & 58.8 & 16.1 & 100.0 & 0.0 & 58.4 & 20.7 & 100.0 \\
\hline
\end{tabular}
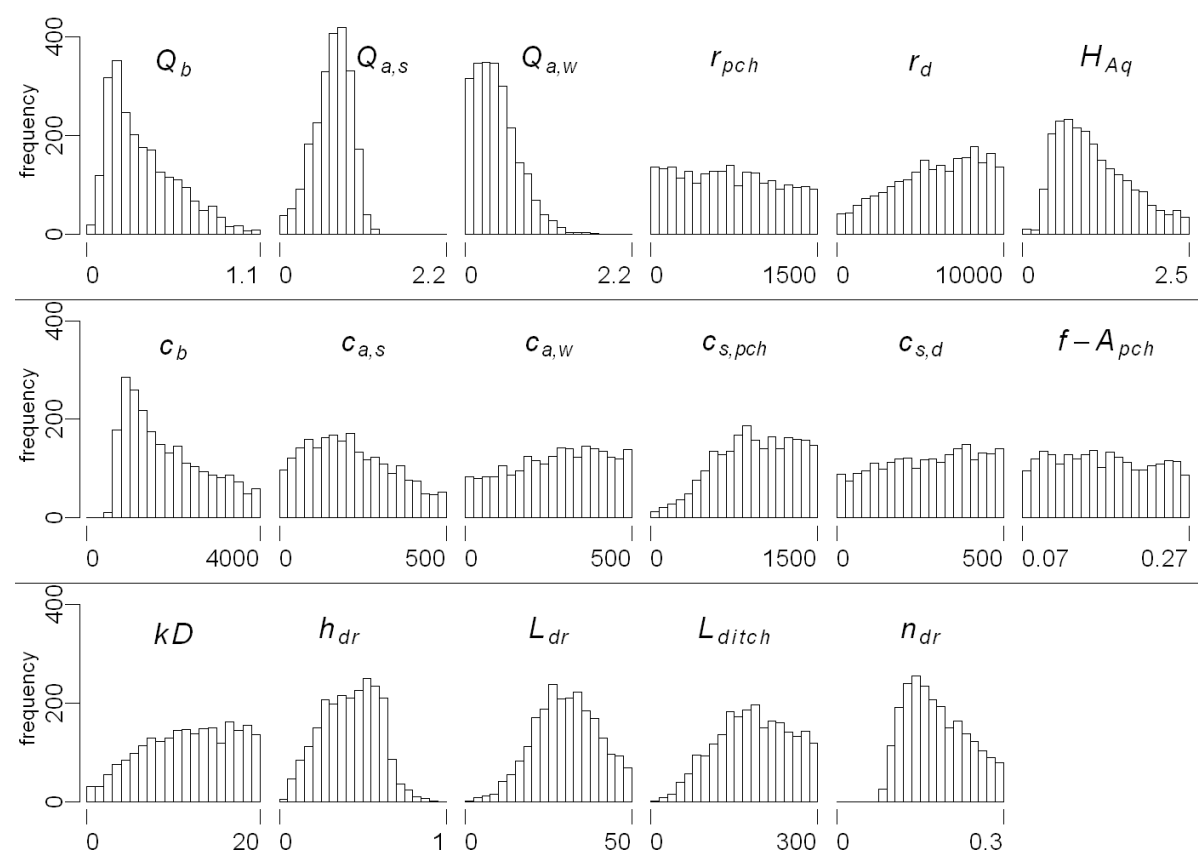

Fig. 5. Posterior behavioural parameter distributions for GLUE analysis GA-B. Units of parameter values are listed in Table 2. 

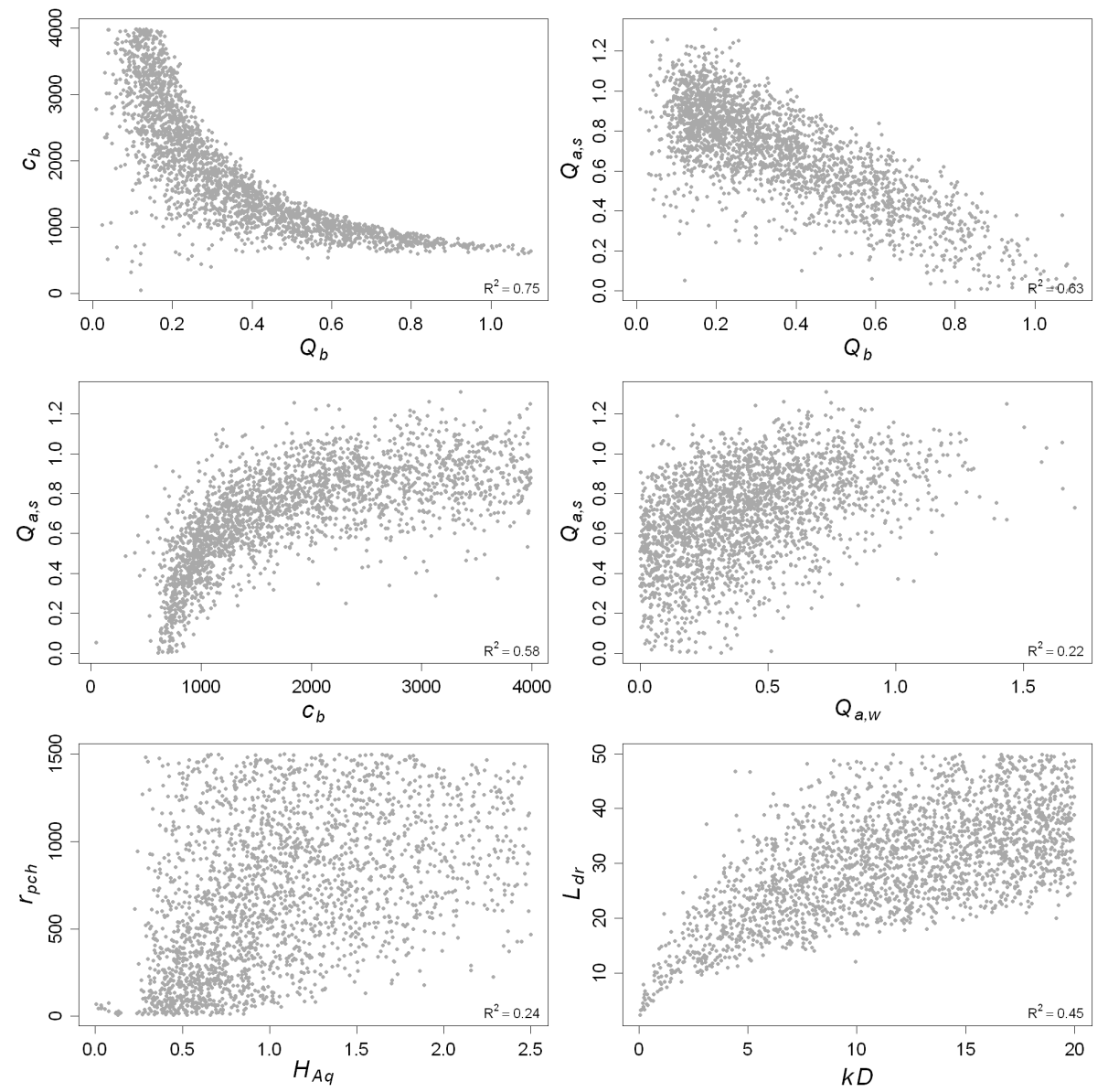

Fig. 6. Scatter diagrams for the six most strongly correlated behavioural parameter combinations (GLUE analysis GA-B).

\subsection{Scenario analysis}

The model was used to calculate the effect and corresponding uncertainty of three different scenarios. We have discussed only the calculated chloride concentrations of the polder water since these reflect water quality rather than loads. For each scenario, the 59630 behavioural parameter sets resulted in an equally large ensemble of day-to-day time series of chloride concentrations of polder discharge. These ensembles can be characterized by the time series of mean and standard deviation of chloride concentration as shown in Fig. 7. As a result of the dryer $w^{+}$climate scenario (used for scenario 1), the chloride concentrations of the surface water are slightly higher in summers compared to the present situation. However, after the summer period, the chloride concentration for the dry $w^{+}$scenario in the months October and November is significantly larger than that for the present situation. During these months the cumulative precipitation deficit between the present and future climate is at its maximum. The model results show that a reduction in the quantity of "boezem" water admitted to the polder (scenario 2) will have a large impact on surface water salinity. During dry periods in the summers, when there is no dilution of the saline seepage water, the average chloride concentration increases from 650 to $840 \mathrm{mg} \mathrm{l}^{-1}$. This is also the period when the demand for fresh water irrigation is the largest. Note that the uncertainty of the predictions increases with increasing salinity during dry periods.

It is possible to take different measures to compensate for the effects of future climate change and sea-level rise. Because boil seepage is the most dominant source of salt, we demonstrated the effect of reducing the contribution from boils by $30 \%$ (scenario 3 ). This leads to a significant decrease in chloride concentrations, from 650 to $410 \mathrm{mgl}^{-1}$, during the dry periods in summer and the chloride concentrations never exceeds $460 \mathrm{mg} \mathrm{l}^{-1}$ (Fig. 7). Note that reducing boil fluxes will probably lead to an increase in the hydraulic head, which will cause an increase of diffuse and paleochannel seepage fluxes. However, since these forms of seepage have a lower salinity, the overall net effect will be positive with respect to the salinization of the surface water. 
Table 5. Global sensitivity analysis results. The $R^{2}$ for correlations between model input parameter values and model output error $€($ tot $=$ entire simulation period, dyn=dynamic, measurement time scale) and the Kolmogorov D statistics for each behavioural parameter distribution from GA-B. Not significant (n.s.) when $R^{2}<0.025$.

\begin{tabular}{|c|c|c|c|c|c|c|c|c|}
\hline & $€($ tot $)-Q_{\text {pump }}$ & $€($ tot $)-L_{\text {pump }}$ & $€($ tot $)-c_{\text {pump }}$ & $€($ dyn $)-Q_{\text {pump }}$ & $€($ dyn $)-L_{\text {pump }}$ & $€($ dyn $)-c_{\text {pump }}$ & $€($ dyn $)-h_{\text {grw }}$ & $D$ \\
\hline$c_{\mathrm{b}}$ & n.s. & 0.320 & 0.490 & n.s. & n.s. & n.s. & n.s. & 0.18 \\
\hline$Q_{\mathrm{b}}$ & 0.143 & 0.322 & 0.201 & n.s. & 0.049 & n.s. & n.s. & 0.38 \\
\hline$H_{\mathrm{aq}}$ & 0.172 & 0.043 & n.s. & n.s. & 0.034 & n.s. & 0.032 & 0.23 \\
\hline$Q_{\mathrm{a}, \mathrm{w}}$ & 0.149 & n.s. & n.s. & 0.070 & 0.034 & n.s. & n.s. & 0.55 \\
\hline$Q_{\mathrm{a}, \mathrm{s}}$ & 0.138 & n.s. & 0.067 & n.s. & 0.090 & n.s. & n.s. & 0.48 \\
\hline$r_{\mathrm{d}}$ & 0.087 & n.s. & n.s. & n.s. & n.s. & n.s. & n.s. & 0.10 \\
\hline$r_{\mathrm{pch}}$ & 0.066 & 0.043 & n.s. & n.s. & n.s. & n.s. & n.s. & 0.10 \\
\hline$l_{\mathrm{dr}}$ & 0.029 & n.s. & n.s. & 0.220 & 0.036 & 0.028 & n.s. & 0.21 \\
\hline$h_{\mathrm{dr}}$ & n.s. & n.s. & n.s. & 0.050 & n.s. & n.s. & 0.337 & 0.25 \\
\hline$l_{\text {ditch }}$ & n.s. & n.s. & n.s. & n.s. & n.s. & n.s. & 0.182 & 0.17 \\
\hline$k D$ & n.s. & n.s. & n.s. & 0.095 & 0.036 & n.s. & 0.136 & 0.09 \\
\hline$c_{\mathrm{a}, \mathrm{s}}$ & n.s. & n.s. & 0.027 & n.s. & 0.097 & 0.039 & n.s. & 0.19 \\
\hline$n_{\mathrm{dr}}$ & n.s. & n.s. & n.s. & 0.085 & 0.051 & 0.077 & 0.049 & 0.24 \\
\hline$c_{\mathrm{s}, \mathrm{p}}$ & n.s. & n.s. & n.s. & n.s. & 0.026 & n.s. & n.s. & 0.16 \\
\hline$A_{\mathrm{pch}}$ & n.s. & n.s. & n.s. & n.s. & n.s. & n.s. & n.s. & 0.09 \\
\hline$c_{\mathrm{s}, \mathrm{d}}$ & n.s. & n.s. & n.s. & n.s. & n.s. & n.s. & n.s. & 0.05 \\
\hline$c_{\mathrm{a}, \mathrm{w}}$ & n.s. & n.s. & n.s. & n.s. & n.s. & n.s. & n.s. & 0.05 \\
\hline
\end{tabular}

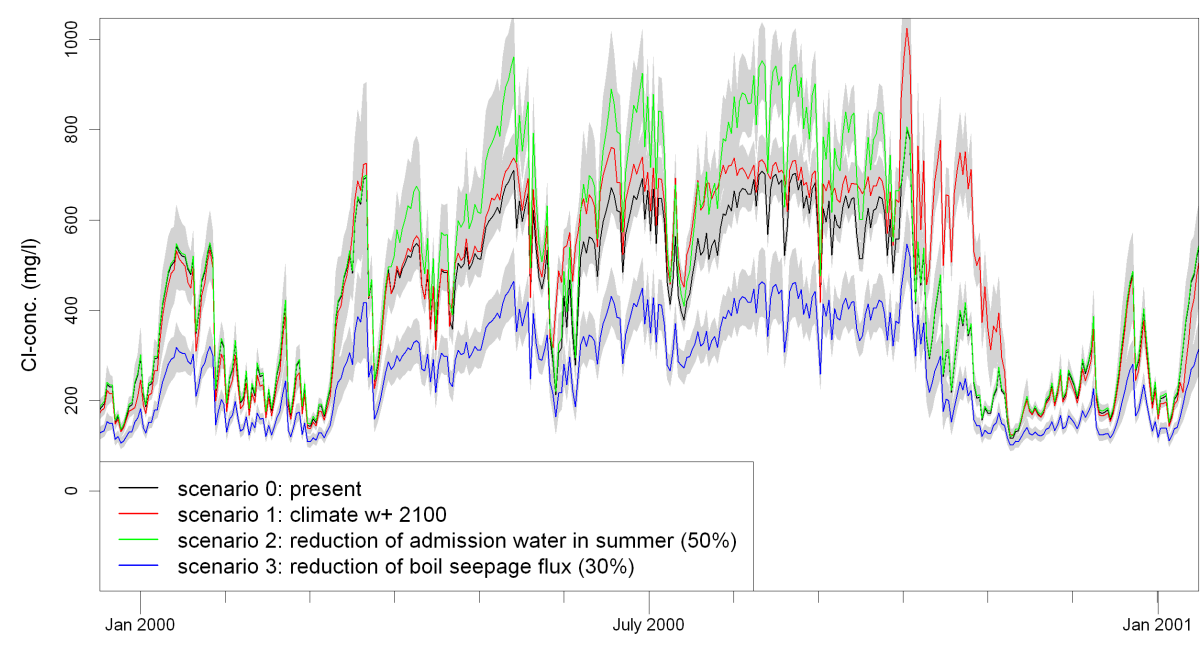

Fig. 7. Calculated chloride concentration of the polder water discharge for different scenarios. The coloured lines give the mean value and the grey areas present the uncertainty range (mean \pm standard deviation) derived from 59630 simulations with behavioural parameter sets of GLUE analysis GA-A.

\section{Conclusions}

In this paper, we have presented a probabilistic (GLUE) endmember mixing approach to modelling daily discharge, salt loads and the salt concentration of water pumped out of an artificially drained polder catchment area. To incorporate the uncertainty of model input parameters, their values were sampled randomly from uniform parameter distributions. The model was conditioned on measurements of daily to weekly polder water discharge, salt concentrations and salt loads leaving the polder and of groundwater levels to produce sets of input parameters which simulate the system equally well. With these sets of behavioural parameters, we quantified the contribution and uncertainty of different sources to the water and salt balance of the polder catchment area and the effects of different scenarios. However, the large variation in behavioural parameter values indicates that there is strong equifinality. This is caused by the presence of the many sources that contribute to the water and salt balance of the polder and by the uncertainty of the model input parameters.

Despite the large equifinality and the uncertainty of many of the model parameters, the dominant salt sources could be quantified within an acceptable reliability. Our modelling 
approach to assessing source contribution demonstrates the need to distinguish preferential from diffuse seepage. These preferential flow paths are discrete and cover just a small part of the polder. However, their localized nature and intense flow at high velocities leads to upconing of deeper groundwater (De Louw et al., 2010). Since salinity increases with increasing depth in the Noordplas Polder, this upconing leads to higher salinities of groundwater being discharged via preferential flow paths than via diffuse seepage. Preferential seepage, which includes upward flow via boils and paleochannel belts, is responsible for about $84 \%$ of the surface water salinization in the polder. The observed polder water discharge, salt concentrations and salt loads could only be explained by assigning a large contribution of the total salt load to boils. Boils contribute, on average, $66 \%$ to the total salt load and only about $15 \%$ to the total water flux into the polder and they therefore form the dominant salinization pathway.

As in most balance studies, discharge rates of water and salt at the polder catchment outlet could be measured relatively accurately as opposed to the incoming fluxes. In particular, uncertainties in the contribution from groundwater seepage are usually large. The model results showed that the equifinality and model input- and output uncertainty can be reduced by narrowing the ranges of the prior parameter distribution. Since our model approach is mainly based on physical and measurable parameters, this can be done by improving the quality of field measurements. Monitoring activities should therefore be concentrated on parameters which are sensitive to the modelled water and salt fluxes. In our case, the most sensitive parameters are boil flux and concentration, and the admission of "boezem" water, which all show significant interdependencies. This implies that focusing monitoring efforts on increasing the accuracy of a single parameter will automatically lead to a greater accuracy of correlated parameters. The estimation of the total boil flux, which is one of the most uncertain and most important parameters, can therefore be improved by collecting accurate data about the admission of "boezem" water or boil water salinity. Our results have established the need for frequent measurements of polder water discharge and weighted concentration at the outlet of the catchment in order to obtain reliable simulations of water and salt fluxes and to be able to allot them to the different sources.

Our findings will help to determine salt reduction measures, as we have now established that such measures should focus on preferential flow paths and, in particular, on boils. Scenario calculations show that if the boil flux can be reduced by $30 \%$, the chloride concentrations will decrease significantly, from 650 to $415 \mathrm{mg} \mathrm{l}^{-1}$ during dry periods in the summers when the demand for fresh water is highest.
Acknowledgements. This research was carried out in collaboration with Rijnland Water Board, Westelijke Land en Tuinbouw Organisation, and Dienst Landelijk Gebied. Part of this research was funded by the Dutch Knowledge for Climate Programme "Fresh Water Availability" and the "Sea and Coast" programme of Wageningen Institute for Environment and Climate Research/Wageningen University. We thank Ronald Bakkum (Rijnland Water Board) and Wiebe Borren (Deltares) for discussions on the balances, Joost Delsman (Deltares), Alexander Vandenbohede (Ghent University), Jackie Senior and the anonymous reviewers for their valuable comments on the paper and Han Bruinenberg (TNO) for the drawings.

Edited by: E. Zehe

\section{References}

Becker, M. W., Georgian, T., Ambrose, H. Siniscalchi, J., and Fredrick, K.: Estimating flow and flux of ground water discharge using water temperature and velocity, J. Hydrol., 296(1-4), 221233, 2004.

Benke, K. K., Lowell, K. E., and Hamilton, A. J.: Parameter uncertainty, sensitivity analysis and prediction error in a water-balance hydrological model, Math. Comput. Modell., 47(11-12), 1134 1149, 2008.

Berendsen, H. J. A., and Stouthamer, E.: Late Weichselian and Holocene palaeogeography of the Rhine-Meuse delta, the Netherlands, Palaeogeogr. Palaeocl., 161(3-4), 311-335, 2000.

Beven, K.: Prophecy, reality and uncertainty in distributed hydrological modeling, Adv. Water Resour., 16(1), 41-51, 1993.

Beven, K.: A manifesto for the equifinality thesis, J. Hydrol., 320(1-2), 18-36, 2006.

Beven, K. J. and Binley, A. M.: The future of distributed models: model calibration and predictive uncertainty, Hydrol. Process., 6, 279-298, 1992.

Blasone, R.-S., Madsen, H., and Rosbjerg, D.: Uncertainty assessment of integrated distributed hydrological models using GLUE with Markov chain Monte Carlo sampling, J. Hydrol., 353(1-2), 18-32, 2008a.

Blasone, R.-S., Vrugt, J. A., Madsen, H., Rosbjerg, D., Robinson, B. A., and Zyvoloski, G. A.: Generalized likelihood uncertainty estimation (GLUE) using adaptive Markov Chain Monte Carlo sampling, Adv. Water Resour., 31(4), 630-648, 2008 b.

Carluer, N. and De Marsily, G.: Assessment and modelling of the influence of man-made networks on the hydrology of a small watershed: implications for fast flow components, water quality and landscape management, J. Hydrol., 285, 76-95, 2004.

Cirkel, D. G., Witte, J. P. M., and van der Zee, S. E. A. T. M.: Estimating seepage intensities from groundwater level time series by inverse modelling: A sensitivity analysis on wet meadow scenarios, J. Hydrol., 385, 132-142, 2010.

Custodio, E. and Bruggeman, G. A.: Groundwater Problems in Coastal Areas, Studies and Reports in Hydrology, UNESCO, International Hydrological Programme, Paris, 1987.

De Louw, P., Oude Essink, G. H. P., Stuyfzand, P. J., and van der Zee, S. E. A. T. M.: Upward groundwater flow in boils as the dominant mechanism of salinization in deep polders, The Netherlands, J. Hydrol., 394, 494-506, 2010. 
Feddes, R. A.: Crop factors in relation to Makkink reference cropevapotranspiration, Evaporation and Weather, CHO-TNO, the Netherlands, Proceedings and information No. 39, 33-45, 1987.

Freer, J., Beven, K., and Ambroise, B.: Bayesian estimation of uncertainty in runoff prediction and the value of data: An application of the GLUE approach, Water Resour. Res., 32(7), 21612173, 1996.

Hijma, M. P., Cohen, K. M., Hoffmann, G., van der Spek, A. J. F., and Stouthamer, E.: From river valley to estuary: the evolution of the Rhine mouth in the early to middle Holocene (western Netherlands, Rhine-Meuse delta), Neth. J. Geosci. - Geologie en Mijnbouw, 88-1, 13-53, 2009.

Hooghoudt, S. B.: General consideration of the problem of field drainage by parallel drains, ditches, watercourses, and channels, Publ. No.7 in the series Contribution to the knowledge of some physical parameters of the soil (titles translated from Dutch), Bodemkundig Instituut, Groningen, The Netherlands, 1940.

Hooper, R. P., Christophersen, N., and Peters, N. E.: Modelling stream water chemistry as a mixture of soil water end-members - An application to the Panola Mountain catchment, Georgia, U.S.A., J. Hydrol., 116(1-4), 321-343, 1990.

Kalbus, E., Schmidt, C., Molson, J. W., Reinstorf, F., and Schirmer, M.: Influence of aquifer and streambed heterogeneity on the distribution of groundwater discharge, Hydrol. Earth Syst. Sci., 13, 69-77, doi:10.5194/hess-13-69-2009, 2009.

Keery, J., Binley, A., Crook, N., and Smith, J. W. N.: Temporal and spatial variability of groundwater-surface water fluxes: Development and application of an analytical method using temperature time series, J. Hydrol., 336, 1-16, 2007.

Kishel, H. F. and Gerla, P. J.: Characteristics of preferential flow and groundwater discharge to Shingobee Lake, Minnesota, USA, Hydrol. Process., 16(10), 1921-1934, 2002.

Kuczera, G. and Parent, E.: Monte Carlo assessment of parameter uncertainty in conceptual catchment models: The Metropolis algorithm, J. Hydrol., 211(1-4), 69-85, 1998.

Makkink, G. F.: Testing the Penman formula by means of lysimeters, J. Inst. Water Eng., 11, 277-288, 1957.

Molenat, J., Gascuel-Odoux, C., Ruiz, L., and Gruau, G.: Role of water table dynamics on stream nitrate export and concentration in agricultural headwater catchment (France), J. Hydrol., 348, 363-378, 2008.

Muleta, M. K. and Nicklow, J. W.: Sensitivity and uncertainty analysis coupled with automatic calibration for a distributed watershed model, J. Hydrol., 306, 127-145, 2005.

Murdoch, L. C. and Kelly, S. E.: Factors affecting the performance of conventional seepage meters, Water Resour. Res., 39(6), SWC21-SWC210, 2003.

Nash, J. E. and Sutcliffe, J. V.: River flow forecasting through conceptual models, Part I: a discussion of principles, J. Hydrol., 10, 282-290, 1970.

Oude Essink, G. H. P.: Impacts of climate change on the coastal groundwater systems in The Netherlands, Proc. 20th Salt Water Intrusion Meeting, June 2008, Naples, Florida, USA, 2008.

Oude Essink, G. H. P., Baaren, E. S., and De Louw, P. G. B.: Effects of climate change on coastal groundwater systems: A modeling study in the Netherlands, Water Resour. Res., 46, W00F04, doi:10.1029/2009WR008719, 2010.
Pappenberger, F., Beven, K., Horritt, M., and Blazkova, S.: Uncertainty in the calibration of effective roughness parameters in HEC-RAS using inundation and downstream level observations, J. Hydrol., 302, 46-69, 2005.

Post, V. E. A. and Abarca, E.: Saltwater and freshwater interactions in coastal aquifers, Hydrogeol. J., 18(1), 1-4, 2010.

Ranjan, P., Kazama, S., and Sawamoto, M.: Effects of climate change on coastal fresh groundwater resources, Global Environ. Change, 16, 388-399, 2006.

Rinaldo, A., Botter, G., Bertuzzo, E., Uccelli, A., Settin, T., and Marani, M.: Transport at basin scales: 1. Theoretical framework, Hydrol. Earth Syst. Sci., 10, 19-29, doi:10.5194/hess-1019-2006, 2006.

Roux, H. and Dartus, D.: Use of parameter optimization to estimate a flood wave: Potential applications to remote sensing of rivers, J. Hydrol., 328(1-2), 258-266, 2006.

Schultz, E.: Water management of the drained lakes in The Netherlands (in Dutch), Ph.D. thesis, Delft University of Technology, Delft, The Netherlands, 1992.

Sherif, M. M. and Singh, V. P.: Effect of climate change on sea water intrusion in coastal aquifers, Hydrol. Process., 13, 12771287, 1999.

Soulsby, C., Petry, J., Brewer, M. J., Dunn, S. M., Ott, B., and Malcolm, I. A.: Identifying and assessing uncertainty in hydrological pathways: A novel approach to end member mixing in a Scottish agricultural catchment, J. Hydrol., 274(1-4), 109-128, 2003.

Spear, R. C. and Hornberger, G. M.: Eutrophication in Peel Inlet, II. Identifcation of critical uncertainties via generalized sensitivity analysis, Water Resour. Res., 14, 43-49, 1980.

Surridge, B. W. J., Baird, A. J., and Heathwaite, A. L.: Evaluating the quality of hydraulic conductivity estimates from piezometer slug tests in peat, Hydrol. Process., 19, 1227-1244, 2005.

Tiemeyer, B., Moussa, R., Lennartz, B., and Voltz, M.: MHYDASDRAIN: A spatially distributed model for small, artificially drained lowland catchments, Ecol. Model., 209(1), 2-20, 2007.

Tiemeyer, B., Lennartz, B., and Kahle, P.: Analysing nitrate losses from an artificially drained lowland catchment (North-Eastern Germany) with a mixing model. Agriculture, Ecosyst. Environ., 123(-3), 125-136, 2008.

Vandenbohede, A., Luyten, K., and Lebbe, L.: Impacts of global change on heterogeneous coastal aquifers: case study in Belgium, J. Coast. Res., 24(2B), 160-170, 2008.

van de Ven, G. P.: Man-made lowlands, history of water management and land reclamation in The Netherlands, Matrijs, Utrecht, 2003.

van den Hurk, B., Klein Tank, A., Lenderink, G., van Ulden, A., van Oldenborgh, G. J., Katsman, C., van den Brink, H., Keller, F., Bessembinder, J., Burgers, G., Komen, G., Hazeleger, W., and Drijfhout, S.: KNMI Climate Change Scenarios 2006 for the Netherlands, Scientific Report WR 2006-01, KNMI, De Bilt, 2006.

van der Eertwegh, G. A. P. H., Nieber, J. L., De Louw, P. G. B., van Hardeveld, H. A., and Bakkum, R.: Impacts of drainage activities for clay soils on hydrology and solute loads to surface water, Irrig. Drain., 55, 235-245, 2006. 
van der Valk, L.: Geology and sedimentology of Late Atlantic sandy, wave-dominated deposits near The Hague (Zuid-Holland, The Netherlands): a reconstruction of an early prograding coastal sequence, Mededelingen Rijks Geologische Dienst, 57, 201228, 1996.

van der Velde, Y., de Rooij, G. H., and Torfs, P. J. J. F.: Catchment-scale non-linear groundwater-surface water interactions in densely drained lowland catchments, Hydrol. Earth Syst. Sci., 13, 1867-1885, doi:10.5194/hess-13-1867-2009, 2009.

van der Velde, Y., Rozemeijer, J. C., De Rooij, G. H., van Geer, F. C., and Broers, H. P.: Fieldscale measurements for separation of catchment discharge into flow route contributions, Vadose Zone J., 9, 25-35, 2010.

van Huissteden, J., Petrescu, A. M. R., Hendriks, D. M. D., and Rebel, K. T.: Sensitivity analysis of a wetland methane emission model based on temperate and arctic wetland sites, Biogeosciences, 6, 3035-3051, doi:10.5194/bg-6-3035-2009, 2009. van Puijenbroek, P. J. T. M., Janse, J. H., and Knoop, J. M.: Integrated modelling for nutrient loading and ecology of lakes in The Netherlands, Ecol. Model., 174(1-2), 127-141, 2004.

van Rees Vellinga, E., Toussaint, C. G., and Wit, K. E.: Water Quality and hydrology in a coastal region of The Netherlands, J. Hydrol., 50, 105-127, 1981.

van Schaik, N. L. M. B.: Spatial variability of infiltration patterns related to site characteristics in a semi-arid watershed, Catena, 78(1), 36-47, 2009.

Weerts, J. T.: Complex Confining Layers. Architecture and hydraulic properties of Holocene and Late Weichselian deposits in the fluvial Rhine-Meuse delta, The Netherlands, Ph.D. thesis, University of Utrecht, 1996.

Wriedt, G., Spindler, J., Neef, T., Meißner, R., and Rode, M.: Groundwater dynamics and channel activity as major controls of in-stream nitrate concentrations in a lowland catchment system, J. Hydrol., 343, 154-168, 2007. 